This is the peer reviewed version of the following article:

Ferrante, Marco; Lövei, Gábor L.; Magagnoli, Serena; Minarcikova, Lenka; Tomescu, Elena Larisa; Burgio, Giovanni; Cagan, Ludovit; Ichim, Mihael Cristin

Predation pressure in maize across Europe and in Argentina: An intercontinental comparison

INSECT SCIENCE 26:3 2019 545-554

which has been published in final form at http://dx.doi.org/10.1111/1744-7917.12550

This article may be used for non-commercial purposes in accordance with Wiley Terms and Conditions for Use of Self-Archived Versions.

\title{
Predation pressure in maize across Europe and in Argentina: an intercontinental
}

\section{comparison}

Marco Ferrante ${ }^{1}$, Gábor L. Lövei ${ }^{1}$, Serena Magagnoli ${ }^{2}$, Lenka Minarcikova ${ }^{3}$, Elena Larisa Tomescu $^{4}$, Giovanni Burgio ${ }^{2}$, Ludovit Cagan $^{3}$ and Mihael Cristin Ichim ${ }^{4}$

${ }^{1}$ Department of Agroecology, Aarhus University, Flakkebjerg Research Centre, Forgøsvej 1, DK4200 Slagelse, Denmark, ${ }^{2}$ Dipartimento di Scienze Agrarie, Area Entomologia, Università di Bologna, Bologna, Italy $;^{3}$ Department of Plant Protection, Faculty of Agrobiology and Food Resources, Slovak Agricultural University, Tr. A. Hlinku 2, SK-949 76 Nitra, Slovakia; ${ }^{4}$ NIRDBS/"Stejarul” Research Centre for Biological Sciences, 6 Alexandru cel Bun St., Piatra Neamt, 610004, Romania.

\begin{abstract}
Humankind draws important benefits from large-scale ecological processes, termed ecosystem services yet the status of several of them is declining. Reliable monitoring
\end{abstract}


methods are essential for tracking the status of ecosystem services. Predation is the mainstay of natural pest control, a key ecosystem service. We used green plasticine caterpillars to monitor predation pressure, and to obtain baseline data on predator activity in transgenic $\mathrm{Bt}$ vs. non-Bt maize fields in Old and New World countries. Predation pressure was measured at ground and canopy levels using an identical, small-plot experimental design in four European countries (Denmark, Slovakia, Romania, Italy) and Argentina. Total predation rate in maize was $11.7 \% \mathrm{~d}^{-1}\left(\min .7 .2 \% \mathrm{~d}^{-1}\right.$ in Argentina, max. $29 \% \mathrm{~d}^{-1}$ in Romania). Artificial caterpillars were attacked both by invertebrates (mostly chewing insects with $42.0 \%$ of the attack marks, and ants with $7.1 \%$, but also predatory and parasitoid wasps, spiders and slugs), and vertebrates (small mammals, $25.5 \%$, and birds $20.2 \%$ ). Total predation at ground level $\left(15.7 \% \mathrm{~d}^{-1}\right)$ was significantly higher than in maize canopies $\left(6.0 \% \mathrm{~d}^{-1}\right)$ in all countries, except Argentina. We found no significant differences between predator pressure in Bt vs. non-Bt maize plots. The artificial caterpillar method provided comparable, quantitative data on predation intensity, and proved to be suitable for monitoring natural pest control. This method usefully expands the existing toolkit by directly measuring ecological function rather than structure.

Keywords: artificial caterpillars; ecosystem services; mortality; sentinel prey; transgenic plants 


\section{Introduction}

Ecosystem services (ESs) are outcomes of ecological processes that provide essential benefits to humans (Daily, 1997). ESs are classified as provisioning, regulating and supporting, and cultural services (Maes et al., 2016). The nature of the relationship between ESs and biodiversity has been long debated (Peterson et al., 1998; Tscharntke et al., 2005), but there is accumulating evidence that high biodiversity enhances the resilience of ESs in space and time (Harrison et al., 2014; Isbell et al., 2015). Because of several unfavourable aspects of human activities linked to agricultural cultivation, including the overuse of artificial fertilisers, pesticides, herbicides, and loss of diversity due to mechanisation and landscape management (Ceballos et al., 2015), the status of many ESs is worsening (MEA, 2005; Carpenter et al., 2009). This raises the need for monitoring ESs (Meyer et al., 2015).

Genetically modified (GM) transgenic plants have been commercially grown since 1995, and have generated profound changes in agricultural practices, leading to documented large, often unexpected environmental consequences in China (Wu et al., 2008; Lu et al., 2010), USA (Stenoien et al., 2017) and Australia (Downes et al., 2017). The general need for environmental impact assessment, including ESs was raised early (Lövei, 2001), and the effect on ESs is now a major concern in Europe in numerous fields (Maltby et al., 2017). In the European Community, post-market environmental monitoring (PMEM) of GM crops is mandatory (Directive 2001/18/EC) so as to detect unwanted, unexpected impacts (EFSA, 2011), but detailed guidance about how such monitoring should be conducted, and how empirical data should be collected, is lacking. The EFSA Guidance (EFSA, 2011) relies on farmer questionnaires, and scanning the literature for outputs of individual research projects. Between 2012-2016, 15 European countries and Argentina collaborated within the AMIGA 
project (“Assessing and Monitoring the Impacts of Genetically Modified Plants on Agroecosystems") which aimed to develop standardised protocols and monitoring tools for PMEM (Arpaia et al., 2014).

Historically, monitoring ESs was done by following changes in the diversity and abundance of the species providing the services ("service providing units", SPUs) (Kontogianni et al., 2010). This creates a taxonomic impediment, because identifying many invertebrate groups requires specialist, or at least taxonomist training. Additionally, the soundness of this approach is doubtful, and measuring ESs directly should be preferred (Furlong \& Zalucki, 2010; Meyer et al., 2015). In the case of biological control provided by natural enemies, which is an important ES among the regulating and supporting ones (Maes et al., 2016), the use of natural enemy diversity or abundance as indicators may easily result in fallacious conclusions. It is not straightforward, for example, that increasing predator diversity enhances the control of pest populations, because negative interactions among insect predators, such as cannibalism or intraguild predation, are frequent (Rosenheim et al., 1995).

Insect predators are important in many pest control strategies (Begg et al., 2017; Gurr et al., 2017), and tracking their activity is desirable under environmental monitoring. Extensive literature exists on methods how to detect arthropod predation, from direct observations to detecting prey DNA from predators (Kidd \& Jervis, 2005; Furlong, 2015; Birkhofer et al., 2017). In comparison to those, the sentinel prey method allows obtaining quantitative estimates, and controlling severeal relevant environmental variables (Meyer et al., 2015). In particular, artificial caterpillars made of plasticine (Howe et al., 2009) are cheap, easy to use, 
and can potentially give more comparable results compared to other sentinel prey (Lövei \& Ferrante, 2017).

In the experiments reported here, our aim was to use artificial caterpillars placed at ground and canopy levels to (i) test whether this could be a useful monitoring method for the necessary GM post-release monitoring toolkit, (ii) record predation intensity in maize, one of the most important crops worldwide (Ranum et al., 2014), as well as invarious consortium partner countries within the AMIGA project, (iii)to establish a baseline for later comparisons and monitoring, and (iv) to compare predation pressure in small transgenic GM vs. non-GM maize plots.

We hypothesised that $(\mathrm{H} 1)$ predation pressure would be higher on the ground than in the maize canopy. We expected this because of the high diversity of ground-active natural enemies in European agricultural fields, which include several predatory arthropod groups, including ground beetles (Coleoptera: Carabidae) (Lövei \& Sunderland, 1996), spiders (Sunderland \& Samu, 2000), ants, and rove beetles (Dahl, 2013), among others. Further, we hypothesized (H2) that predation pressure in Argentina will be higher than in Europe. Maize relatives (Zea spp.) are native to the Americas (Ranum et al., 2014), where there has been an opportunity for a rich trophic network associated with that plant and its herbivores to develop, while maize was only brought to Europe in 1492 (Mann, 2011), and thus has not had this evolutionary opportunity. We also expected that predation pressure will reflect the biodiversity gradient within Europe from north-west to south-east: the natural enemy assemblages in cultivated land in general are much more species-rich in SW Europe than further north and west (Mészáros et al., 1984; Báldi et al., 2013), although agricultural practice and pesticide use can have important influence (Lüscher et al., 2014). Agriculture in 
Europe is more intensive and relies on higher chemical inputs in the northern and northwestern countries, with deleterious effects on biodiversity (De Ponti et al., 2012). Consequently, (H3) we expected that predation intensity in Northern Europe would be lower than in Southern, and especially south-eastern Europe, as biodiversity generally increases towards the Equator (Gaston, 2000).

Our results indicated high predation pressure at or near ground level, but much lower on maize canopies. There was higher predation on artificial caterpillars on maize canopies in Argentina vs. Europe, and our hypothesis about the predation pressure gradient within Europe was supported: significantly more caterpillars were attacked in Slovakia and Romania than in Denmark or Italy. The use of artificial caterpillars is suitable as a monitoring method in postrelease monitoring of field-grown transgenic crops.

\section{Methods}

Study sites

Predation pressure was measured using the artificial caterpillar method (Howe et al., 2009) near Slagelse, on the island of Zealand in Denmark (2014-2016), near Nitra in western Slovakia (2013-2014), near Secuieni in north-est Romania (2014-2015), and in EmiliaRomagna in Northern Italy (2014-2015), and near Córdoba in central Argentina (2016) (for precise locations, see Table S1). All these countries are major maize producer in Europe (except Denmark and Slovakia, Dewar 2009) or South America (FAOStat, 2017), and were characterised by mixed cultivated landscape typical of research stations. The same field arrangement was used in all countries, (except in Italy where only isogenic maize was used, 
because field-growing of transgenic plants is not allowed). The experimental design consisted of 20 randomised plots; ten of transgenic maize, and ten of its near-isogenic line. Individual maize plants were $0.6 \mathrm{~m}$ apart, and rows were $0.8 \mathrm{~m}$ apart. In Romania, an additional treatment (transgenic maize, isogenic line grown conventionally, and isogenic line grown using an Integrated Pest Management method, four plots for each treatment) was also performed, and data are included from this additional experiment. In Denmark, Slovakia and Romania, identical maize cultivars (DKC3872YG; and DKC3871 as control) were used, but not in Argentina, where the local plant varieties were different (for details see Table S1).

\section{Measuring predation rates}

Individual caterpillars $(15 \mathrm{~mm}$ length $\mathrm{x} 3 \mathrm{~mm}$ diameter, made of unscented green plasticine [Smeedi plus V. nr. 776609] ) were glued with instant glue gel (Attack) to a piece of reed (ca.35 mm long, $6 \mathrm{~mm}$ wide) and placed at ground level touching maize stems as if the caterpillars were climbing the stem (Fig. 1). In each plot, sentinels were placed at the base of eight randomly selected plants (only 4 in Romania), but with the constraint that they could not be any of the two neighbouring plants in any direction (min. $1.8 \mathrm{~m}$ distance between single sentinels), nor the outmost plant of the plot. A further eight larvae were pinned (Denmark 2014-2015, and Argentina) or glued (Slovakia, and Italy) on the leaves of the same plants on the third leaf from the top (starting when plants were approximately150-200 mm tall). Predation intensity in the maize canopy was not measured in Romania.

Artificial caterpillars were used during the entire growing season (see Table S1 for details). In 2013, five sentinel prey sessions were performed with a total of 1280 caterpillars in 
Denmark, and three sessions with 960 caterpillars in Slovakia; in 2014, four session with 1120 and 512 caterpillars in Denmark and Romania, respectively, three sessions with 960 caterpillars in Slovakia, and five sessions with 2144 caterpillars in Italy. In 2015, five sessions were done with 1120 exposed caterpillars in Denmark, and three each with 384 and 1056 caterpillars in Romania, and Italy, respectively. In Argentina, during the southern summer of 2015-2016, 1601 caterpillars were exposed to predators during seven sessions. This led to an overall total of 11137 artificial caterpillars used.

In all sessions, artificial caterpillars were exposed for $24 \mathrm{~h}$, after which they were collected and predation marks identified using a hand-held lens (12× magnification) in the field, and cross-checked in the laboratory under a binocular microscope using our own photographic records or published information (Ferrante et al., 2014; Low et al., 2014). All identifications were done by either MF or GLL except the Italian samples, which were identified by SM. Multiple attack marks by the same predator group were assumed to originate from the same predator, but signs by different predator types were considered independent attacks. Very few caterpillars (294/11 456, 0.02\%) were lost, and these were excluded from the analysis. Most of these $(n=110)$ were artificial caterpillars glued to leaves in Denmark in 2013, which were dislodged by neighbouring leaves moved by the wind. These were all left out even if they were found on the ground at inspection.

\section{Statistical analysis}

Sentinels on the ground and in the maize canopy were on the same plant. It is unlikely that they were not independent, as very few ground-active predators will climb maize plants 
(Lövei \& Szentkirályi, 1984), but we analysed them separately. Predation on artificial caterpillars was analysed by generalised linear mixed models (GLMM). Maize type (GM or non-GM), and location (country) were fixed factors, plot was a random factor, and there were no interactions between factors. The post-hoc Tukey $t$-test was used to determine the significance of the results. Mean predation rates within the same country in different years were tested using the post-hoc Tukey test on a logistic regression with country and year as fixed factors. Similarity among predator assemblages was calculated using the Bray-Curtis index. All statistical analyses were performed using the statistical program R, version 3.1.1 (R Core Team, 2015), and the 'vegan' package (Oksanen et al., 2015).

\section{Results}

Overall, $11.7 \%(1265 / 10843)$ of the artificial caterpillars were attacked after the $24 \mathrm{~h}$ exposure. The identified predator groups included invertebrates (mostly chewing insects with $42.0 \%$ of the bites, ants with $7.1 \%$, predatory and parasitoid wasps, slugs, spiders and unknown arthropods, with $1.9 \%$ all together), and vertebrates (small mammals, $25.5 \%$, and birds $20.2 \%$ ). Total predation was significantly higher (Student's $t$-test: $t=16.8, P<0.001$ ) at ground level $\left(\right.$ mean $\left.=15.7 \% \mathrm{~d}^{-1}, \mathrm{SD}=36.3 \% \mathrm{~d}^{-1}, N=6379\right)$ than on the maize canopy $\left(\right.$ mean $\left.=6.0 \% \mathrm{~d}^{-1}, \mathrm{SD}=23.7 \% \mathrm{~d}^{-1}, N=4464\right)$. There was no significant difference (GLMM: $Z$ $=0.7, P>0.05)$ between overall predation rates in plots of transgenic Bt- $\left(\right.$ mean $=12.7 \% \mathrm{~d}^{-1}$, $\left.\mathrm{SD}=33.3 \% \mathrm{~d}^{-1}, n=3773\right)$ vs. non-Bt maize $\left(\right.$ mean $\left.=11.1 \% \mathrm{~d}^{-1}, \mathrm{SD}=31.4 \% \mathrm{~d}^{-1}, n=7070\right)$. 
Predation intensity on caterpillars at ground level (Fig 2) at the Romanian site was significantly higher (Tukey's $t$-test, $z=-3.4-10.1, P<0.007-0.001$ ) than in any other studied location. Ground-placed caterpillars in Slovakia were also attacked significantly more than in Denmark, Italy, or Argentina (Tukey's $t$-test, $z=4.0-7.5, P<0.001$ for all comparisons). There were no significant differences (Tukey's $t$-test, $z=0.2, P=1.0$ ) in ground-level predation intensity between Italy and Denmark, but both were significantly higher (Tukey's $t$-test, $z=3.5-3.9, P=0.001-0.004$ ) than in Argentina.

Predation intensity on maize-canopy in Slovakia was significantly higher (Tukey's $t$-test, $z=$ $2.9-8.0, P<0.001$, Argentina $P=0.014$ ) than elsewhere (Fig 2). Maize canopy predation intensities were not significantly different (Tukey's $t$-test, $z=-1.4, P=0.493$ ) between Denmark and Argentina, but both were significantly higher than the canopy predation measured in Italy (Table 1).

\section{Predator assemblages}

In Romania, caterpillars were only placed at ground level and most attacks were by vertebrates: small mammals were responsible for $68.1 \%$ of the bites, birds for $17.6 \%$, and the share of unidentified vertebrates was 3.7\%.Invertebrates included chewing insects $(11.4 \%$ of attacks), and ants (0.8\%). In Slovakia, most attacks were by invertebrates (chewing insects $39.0 \%$, ants $24.0 \%$ ). A few spider (1.3\%), slug and parasitoid marks ( $0.6 \%$ for each) were also found. Attacks by vertebrates were fewer: small mammals had a $31.0 \%$ share, and birds were responsible for $8.3 \%$ of the attacks. In Denmark, more attacks were by vertebrates (birds, 43.5\%, small mammals, 11.1\%), than invertebrates (chewing insects, $29.7 \%$, plus two 
spiders, and a single wasp attack mark). Unknown bites accounted for $15.3 \%$ of the bites. In Italy, $74.2 \%$ of the attacks were by invertebrates (chewing insects $66.9 \%$, wasps $3.1 \%$, ants $2.3 \%$, unidentified arthropods $1.9 \%$ ); vertebrates made $24.2 \%$ of the attacks (birds $15.4 \%$, small mammals 8.8\%). Almost all predators in Argentina were chewing insects $(93.9 \%$ of the bites); only a few marks were attributed to ants (5.3\%), and a single caterpillar (0.9\%) had a bird mark.

We compared the "activity profiles" of the predator assemblages. Argentina and Italy had similar predator assemblage activity profiles both at ground and maize-canopy levels (Figs. S1, S2). In the case of ground-level predation, assemblage activity profiles in Romania and Slovakia were similar, and the Danish one close but separate from this cluster. At canopy level, Denmark and Slovakia demonstrated similar profiles (Table 2).

\section{Predation within location, between years}

Multi-year data were available from locations in Romania, Slovakia, Denmark, and Italy (Table S1). In Romania, predation rate in 2014 at ground level $\left(\right.$ mean $=37.1 \% \mathrm{~d}^{-1}, \mathrm{SD}=$ $48.4 \% \mathrm{~d}^{-1}, n=304$ ) was significantly higher (Tukey's $t$-test, $z=-5.0, P<0.001$ ) than in 2015 $\left(\right.$ mean $\left.=17.1 \% \mathrm{~d}^{-1}, \mathrm{SD}=37.7 \% \mathrm{~d}^{-1}, n=228\right)$.

In Slovakia: predation rate on ground caterpillars in $2013\left(\right.$ mean $=14.8 \% \mathrm{~d}^{-1}, \mathrm{SD}=35.5 \% \mathrm{~d}^{-1}$, $n=480$ ) was significantly lower (Tukey's $t$-test, $z=5.0, P<0.001)$ than in 2014 (mean $=$ $\left.28.1 \% \mathrm{~d}^{-1}, \mathrm{SD}=45.0 \% \mathrm{~d}^{-1}, n=477\right)$. Predation rate in the maize canopy in $2013($ mean $=$ 
$12.7 \% \mathrm{~d}^{-1}, \mathrm{SD}=33.3 \% \mathrm{~d}^{-1}, n=480$ ) was not significantly different (Tukey's $t$-test, $z=-1.4, P$ $=0.841)$ than in $2014\left(\right.$ mean $\left.=9.8 \% \mathrm{~d}^{-1}, \mathrm{SD}=29.8 \% \mathrm{~d}^{-1}, n=479\right)$.

In Denmark, there was no significant difference (Tukey's $t$-test, $z=-0.5, P=1.0$ ) between predation rates in $2013\left(\right.$ mean $\left.=17.0 \% \mathrm{~d}^{-1}, \mathrm{SD}=37.6 \% \mathrm{~d}^{-1}, n=787\right)$ and $2014($ mean $=$ $\left.16.1 \% \mathrm{~d}^{-1}, \mathrm{SD}=36.7 \% \mathrm{~d}^{-1}, n=635\right)$ but it decreased significantly (Tukey's $t$-test, $z=-6.5$ to 7.9 both $P<0.001)$ in $2015\left(\right.$ mean $\left.=4.4 \% \mathrm{~d}^{-1}, \mathrm{SD}=20.5 \% \mathrm{~d}^{-1}, n=639\right)$. Similarly, predation rates in the maize canopy in $2013\left(\right.$ mean $\left.=3.2 \% \mathrm{~d}^{-1}, \mathrm{SD}=17.7 \% \mathrm{~d}^{-1}, n=371\right)$ and $2014($ mean $\left.=4.3 \% \mathrm{~d}^{-1}, \mathrm{SD}=20.3 \% \mathrm{~d}^{-1}, n=466\right)$ were not significantly different (Tukey’s $t$-test, $z=0.7, P$ $=0.993)$, but in $2015\left(\right.$ mean $\left.=9.0 \% \mathrm{~d}^{-1}, \mathrm{SD}=28.6 \% \mathrm{~d}^{-1}, n=412\right)$, predation was significantly higher (Tukey's $t$-test, $z=3.2, P=0.02$ ) than 2013, and marginally so (Tukey's $t$-test, $z=2.8$, $P=0.1)$ than in 2014 .

In Italy, predation rate at ground level in $2014\left(\right.$ mean $\left.=11.5 \% \mathrm{~d}^{-1}, \mathrm{SD}=31.9 \% \mathrm{~d}^{-1}, n=1195\right)$ was lower (Tukey's $t$-test, $z=3.2, P=0.055)$ than in $2015\left(\right.$ mean $=17.1 \% \mathrm{~d}^{-1}, \mathrm{SD}=37.7 \% \mathrm{~d}^{-1}$, $n=527$ ), but there was no significant difference (Tukey's $t$-test, $z=0.1, P=1.0$ ) between

predation rates at maize canopy level in the two years $\left(2014\right.$ mean $=2.2 \% \mathrm{~d}^{-1}, \mathrm{SD}=14.8 \% \mathrm{~d}^{-1}$, $n=938 ;$ and 2015 mean $\left.=2.3 \% \mathrm{~d}^{-1}, \mathrm{SD}=15.0 \% \mathrm{~d}^{-1}, n=524\right)$.

\section{IPM experiment in Romania}

In Romania, there were no significant differences (Tukey's $t$-test: $z=-1.3-0.3$, all $P>0.05$ ) between predation rates in $\mathrm{Bt}$ maize plots (mean $\left.=34.6 \% \mathrm{~d}^{-1}, \mathrm{SD}=47.8 \% \mathrm{~d}^{-1}, n=104\right)$, non- 
Bt plots grown conventionally $\left(\right.$ mean $\left.=31.4 \% \mathrm{~d}^{-1}, \mathrm{SD}=46.6 \% \mathrm{~d}^{-1}, n=102\right)$, or IPM methods $\left(\right.$ mean $\left.=23.4 \% \mathrm{~d}^{-1}, \mathrm{SD}=42.5 \% \mathrm{~d}^{-1}, n=107\right)$. 


\section{Discussion}

Our detected predation rates were in the high range with respect to available data from various geographical locations and habitats (Lövei \& Ferrante, 2017). Data, however, are scarce from agricultural habitats, and in some of these (e.g. Lemessa et al., 2015), methodological differences make comparisons impossible. Our data on predation rates are conservative, because they do not include predation pressure by predators that use traps to capture active prey. For example, web-building spiders (Riechert \& Lockley, 1984) and parasitoids (Kidd \& Jervis, 2005) are important natural enemies, yet their impact is certainly underrepresented by our method. Differences in the composition of the predator assemblage only partially can explain the registered differences. The north-south gradient was only partially apparent in our study, in that at our Italian location did not have the highest predation pressure, which can be related to a practice of chemical-intensive agriculture, typical of much of Western and Southwestern Europe (Kleijn et al., 2009). The effect of agricultural practice is also seen in the higher predation pressure in Eastern and South-eastern Europe, where agriculture is still less intensive, resulting in higher diversity and more natural pest control (Kleijn et al., 2009). The high predation rates of small mammal predation that we found in Romania and Slovakia are consistent with the observed increase in rodent diversity toward East Europe (Kryštufek \& Griffiths, 2002). Curiously, predation pressure in at the Argentinian location was not higher than at the European ones, but predation pressure in the maize canopy was equal to the ground-level one, being the only one among the locations examined. This is consistent with the long evolutionary history hypothesis, at least for aboveground (canopy) predators. The low predation pressure could be a landscape factor, as the experimental station was in the outskirts of the town of Córdoba, with extensive urbanisation and large-scale maize cultivation. 
Lövei and Ferrante (2017) analysed the predation intensity on artificial caterpillars in forests by geographical latitude, and found no significant increase from north to south. At the time, there were insufficient data to attempt a similar analysis for cultivated habitats. With several new data points added by this paper, such an analysis can now be attempted (Fig. 3). Interestingly, there was a significant positive relationship found for predation by vertebrates, but not for invertebrates (Fig. 3). It has to be kept in mind, however, that our data do not always originate from the same year and the maize cultivars were also occasionally different, so only limited generalisations can be drawn from our predation data.

Our hypothesis of higher predation pressure at ground level vs. on maize canopies in Europe was supported. Although a high number of species could be found in maize in Europe (Mészáros et al., 1984; Dahl, 2013), many of these are probably "tourists" that have no trophic link to maize. In Europe, there are few maize-specific herbivores, although several Lepidoptera and aphids have included this relatively new plant in their host plant range (Dahl, 2013). One of them, the pyralid Ostrinia nubilalis inadvertently transported to North America, even became an important pest there, giving the original impetus to develop the insect resistant transgenic (Bt) maize (Koziel et al., 1993). It seems that the soil-based food web is more resistant to the appearance of a new above-ground host plant, and the European ground-active predators successfully colonised or survived in the new, maize -dominated habitats. 
We found no difference in overall predation pressure between our GM vs. non-GM maize plots at any location in any year. This is in line with no aversion of $B t$ maize plants by egglaying insects (Obonyo et al., 2008). Bt-residues can be detected in the soil (Icoz \& Stotzky, 2008) and in soil-based food chains (Andow \& Zwahlen, 2016) but their eventual effect is unclear. Earthworms do not seem to be adversely affected by Bt maize (Zeilinger et al., 2010), and they are important prey for ground beetles (Lövei \& Sunderland, 1996). Ground beetles are a very common arthropod group in maize fields (Lövei, 1984; Lee \& Albajes, 2016), and may be responsible for a substantial share of attacks on artificial caterpillars (Mansion-Vaquié et al., 2017). We recorded a very high number of carabids in the experimental plots in Denmark (Di Grumo \& Lövei, 2016).

Monitoring has become a very important goal, mainly due to the multitude of harms we are causing nature, as well as to processes useful to ourselves, humans (Carpenter et al., 2009). In the case of field-grown transgenic crops,monitoring is obligatory (Arpaia et al., 2014). In general, however, the practice of monitoring leaves much to desire, and recommendations and instructions are lacking. All too often the basic steps of identifying the necessary elements, the indicandum (the phenomenon of interest that we want information on), the appropriate indicator (the organism that can indicate the phenomenon with the desired precision and sensitivity), and the index (the appropriate parameter to measure), are lacking (Lövei, 2014). The existence of the universal principle of indication states that every organism is an indicator. By its very presence, the organism indicates the presence of a set of conditions that are necessary for its existence and survival at the given location. This is great relief to specialists who routinely argue that their favourite group is "a good indicator" (see, for carabids, Koivula, 2011, for syrphids, Sommaggio, 1999, for isopods, Dallinger et al., 
1992, etc.). They are right, but no organism is a good indicator for everything, and the above relationships have to be established for every indication task, specifying first what is to be indicated?

Added to this is the "structure for function" paradox. In many cases, we are interested in the conditions, or intensity of an ecological function, mostly because of its utilitarian value. This utilitarian interest leads to the need of monitoring the status of various ecosystem services. However, the existing ecological toolkit, better in monitoring densities and distribution, causesthis interest in a function diverted to monitoring the changes in the distribution, diversity or density of selected SPUs. Only recently have we started to realise that there is no direct nor easy translation between ecological structure and ecological function, which lead to calls to develop and use methods by which we can track function intensity directly (Meyer et al., 2015), rather than their proxies in terms of SPUs.

The field experiments reported here constitute empirical evidence that thegreen artificial caterpillar prey is attractive to a wide range of potential predators, and is easy to use under field conditions. Some biological knowledge, allowing the recognition of marks left by various predators, increases the information to be obtained from the method, but a rough estimate of general predation pressure can be done with a minimum of such knowledge. We conclude that the artificial caterpillar method is useful to monitor the intensity of natural pest control under a wide range of field conditions, and is useful for the large-scale environmental monitoring of field-grown transgenic plants as mandatory in the European Community. 


\section{Acknowledgments}

We thank G. Barone, E. Bozóné-Borbáth, D. Di Grumo, M. Kiss, A. Lo Cacciato, A. Mansion-Vaquié, D. Nagy, N.Patelli, and U. Pilegård Larsen in Denmark, A. Andrei, R.M. Ciubotaru, E.R. Irimia, M.O. Popa, A. Rosca, E.A. Sicora and P.P. Sosoi in Romania, G. Aguilera, J.B. Beltrami, L.N. CuraF. Fava, J. Finello, J.I. Leguizamos, G. Rojo, and N.F. Somale, in Argentina for technical assistance in the field and the laboratory, E. Trumper and J. Edelstein $(\dagger)$ for support, and two anonymous reviewers for comments on the manuscript. This is output no. 21 of the AMIGA Project, supported by the EC (grant agreement No. 289706) and is in partial fulfilment of the $\mathrm{PhD}$ requirements at Aarhus University (MF). MCI and ELT acknowledge co-funding from the Romanian Executive Unit for Financing Higher Education, Research, Development and Innovation under PNCDI II / Capacities Program / Module III - (contract no. 199EU); LM and LC acknowledge partial funding from the Slovak Scientific Agency VEGA (Grant No. 1/0732/14). Author contributions: experimental design: MF \& GL; field work by all authors at their respective field sites, identification of predation marks MF, GL, SM, data evaluation, MF \& GL, writing MF \& GL, with input from all authors. Author sequence is according the "sequence by merit" principle.

\section{Disclosure}

The authors disclose no conflicts of interest of any kind associated with this manuscript 


\section{References}

Andow, D. and Zwahlen, C. (2016) Ground beetle acquisition of Cry1Ab from plant-and residue-based food webs. Biological Control, 103, 204-209.

Arpaia, S., Messéan, A., Birch, N.et al. (2014) Assessing and monitoring impacts of genetically modified plants on agro-ecosystems: the approach of AMIGA project. Entomologia, 2, 79-86.

Báldi, A., Batáry, P. and Kleijn, D. (2013) Effects of grazing and biogeographic regions on grassland biodiversity in Hungary-analysing assemblages of 1200 species. Agriculture, Ecosystems \& Environment, 166, 28-34.

Begg, G.S., Cook, S.M., Dye, R.et al. (2017) A functional overview of conservation biological control. Crop Protection, 97, 145-158.

Birkhofer, K., Bylund, H., Dalin, P., Ferlian, O., Gagic, V., Hambäck, P.A., et al. (2017) Methods to identify the prey of invertebrate predators in terrestrial field studies. Ecology and Evolution, 7, 1942-1953.

Carpenter, S.R., Mooney, H.A., Agard, J., Capistrano, D., Defries, R.S., Diaz, S., et al. (2009) Science for managing ecosystem services: Beyond the Millennium Ecosystem Assessment. Proceedings of the National Academy of Sciences USA, 106, 1305-1312.

Ceballos, G., Ehrlich, P.R., Barnosky, A.D., García, A., Pringle, R.M. and Palmer, T.M. (2015) Accelerated modern human-induced species losses: Entering the sixth mass extinction. Science Advances, 1, e1400253.

Dahl, R. 2013. Generalization of monitoring of beneficial arthropod fauna in maize and potato fields for future GM monitoring. Unpublished MSc Thesis, University of Aarhus, Denmark. 26 pp. 
Daily, G. (1997) Nature's Services: Societal Dependence on Natural Ecosystems, Island Press, Washington DC, USA.

Dallinger, R., Berger, B. and Birkel, S. (1992) Terrestrial isopods: useful biological indicators of urban metal pollution. Oecologia, 89, 32-41.

De Ponti, T., Rijk, B. and van Ittersum, M.K. (2012) The crop yield gap between organic and conventional agriculture. Agricultural Systems, 108, 1-9.

Dewar, A.M. (2009). Weed control in glypohsate-tolerant maize in Europe. Pest Management Science, 67, 1045-1058.

Di Grumo, D. and Lövei, G. L. (2016) Body size inequality in ground beetle (Coleoptera: Carabidae) assemblages as a potential method to monitor environmental impacts of transgenic crops. Periodicum Biologorum, 118, 223-230.

Downes, S., Kriticos, D., Parry, H., Paull, C., Schellhorn, N. and Zalucki, M.P. (2017) A perspective on management of Helicoverpa armigera: transgenic Bt cotton, IPM, and landscapes. Pest Management Science, 73, 485-492.

EFSA Panel on GMO (2011) Scientific Opinion on guidance on the Post-Market Environmental Monitoring (PMEM) of genetically modified plants. EFSA Journal, 9, 2316.

FAOStat (2017) Crop Statistics Database. http://www.fao.org/faostat/en/\#data/QC (accessed 24/07/17).

Ferrante, M., Lo Cacciato, A. and Lövei, G.L. (2014) Quantifying predation pressure along an urbanisation gradient in Denmark using artificial caterpillars. European Journal of Entomology, 111, 649-654.

Furlong, M. J., and Zalucki, M. P. (2010) Exploiting predators for pest management: the need for sound ecological assessment. Entomologia Experimentalis et Applicata, 135, 225236. 
Furlong, M.J. (2015) Knowing your enemies: Integrating molecular and ecological methods to assess the impact of arthropod predators on crop pests. Insect Science, 22, 6-19.

Gaston, K.J. (2000) Global patterns in biodiversity. Nature, 405, 220-227.

Gurr, G.M., Wratten, S.D., Landis, D.A. and You, M.S. (2017) Habitat management to suppress pest populations: Progress and prospects. Annual Review of Entomology, 62, 91-109.

Harrison, P., Berry, P., Simpson, G., Haslett, J.R., Blicharska, M., Bucur, M., et al. (2014) Linkages between biodiversity attributes and ecosystem services: a systematic review. Ecosystem Services, 9, 191-203.

Howe, A., Lövei, G.L. and Nachman, G. (2009) Dummy caterpillars as a simple method to assess predation rates on invertebrates in a tropical agroecosystem. Entomologia Experimentalis et Applicata, 131, 325-329.

Icoz, I. and Stotzky, G. (2008) Fate and effects of insect-resistant Bt crops in soil ecosystems. Soil Biology and Biochemistry, 40, 559-586.

Isbell, F., Craven, D., Connolly, J., Loreau, M., Schmid, B., Beierkuhnlein, C. et al. (2015) Biodiversity increases the resistance of ecosystem productivity to climate extremes. Nature, 526, 574-577.

Kidd, N.A. and Jervis, M.A. (2005) Population dynamics. Insects as Natural Enemies (ed. N.A. Jervis), pp. 435-523. Springer, Dordrecht, Netherlands.

Kleijn, D., Kohler, F., Báldi, A., Batáry, P., Concepcion, E.D., Clough, Y. et al. (2009) On the relationship between farmland biodiversity and land-use intensity in Europe. Proceedings of the Royal Society of London B: Biological Sciences, 276, 903-909. 
Koivula, M. (2011) Useful model organisms, indicators, or both? Ground beetles (Coleoptera, Carabidae) reflecting environmental conditions. ZooKeys, 100, 287-317.

Kontogianni, A., Luck, G.W. and Skourtos, M. (2010) Valuing ecosystem services on the basis of service-providing units: A potential approach to address the 'endpoint problem'and improve stated preference methods. Ecological Economics, 69, 14791487.

Koziel, M.G., Beland, G.L., Bowman, C., Carozzi, N.B., Crenshaw, R., Crosslan, L. et al. (1993) Field performance of elite transgenic maize plants expressing an insecticidal protein derived from Bacillus thuringiensis. Nature Biotechnology, 11, 194-200.

Kryštufek, B. and Griffiths, H.I. (2002). Species richness and rarity in European rodents. Ecography, 25, 120-128.

Lee, M.S. and Albajes, R. (2016) Monitoring carabid indicators could reveal environmental impacts of genetically modified maize. Agricultural and Forest Entomology, 18, 238249.

Lemessa, D., Hambäck, P.A. and Hylander, K. (2015) Arthropod but not bird predation in Ethiopian homegardens is higher in tree-poor than in tree-rich landscapes. PLoS ONE, 10, e0126639.

Lövei, G.L. (2001) Ecological risks and benefits of transgenic plants. New Zealand Plant Protection, 54, 93-100.

Lövei, G.L. (1984) Ground beetles(Coleoptera: Carabidae) in two types of maize fields in Hungary. Pedobiologia, 26, 57-64.

Lövei, G.L. (2014) Thoughts of a travelling ecologist, 6. On Monitoring. Journal of Biosafety, 23, 1-3. 
Lövei, G.L. and Ferrante, M. (2017) A review of the sentinel prey method as a way of quantifying invertebrate predation under field conditions. Insect Science, 24, 528542.

Lövei, G.L. and Sunderland, K.D. (1996) Ecology and behavior of ground beetles (Coleoptera: Carabidae). Annual Review of Entomology, 41, 231-256.

Lövei, G.L. and Szentkirályi, F. (1984) Carabids climbing maize plants. Zeitschrift für Angewandte Entomologie, 97, 107-110.

Low, P.A., Sam, K., Mcarthur, C., Posa, M.R.C. and Hochuli, D.F. (2014) Determining predator identity from attack marks left in model caterpillars: guidelines for best practice. Entomologia Experimentalis et Applicata, 152, 120-126.

Lu, Y.H., Wu, K.M., Jiang, Y.Y., Xia, B., Li, P., Feng, H.Q. et al. (2010) Mirid bug outbreaks in multiple crops correlated with wide-scale adoption of $\mathrm{Bt}$ cotton in China. Science, 328, 1151-1154.

Lüscher, G., Jeanneret, P., Schneider, M.K., Turnbull, L.A., Arndorfer, M., Balazs, K. et al. (2014) Responses of plants, earthworms, spiders and bees to geographic location, agricultural management and surrounding landscape in European arable fields. Agriculture, Ecosystems \& Environment, 186, 124-134.

Maes, J., Liquete, C., Teller, A., Erhard, M., Paracchini, M.L., Barredo, J. et al. (2016) An indicator framework for assessing ecosystem services in support of the EU Biodiversity Strategy to 2020. Ecosystem Services, 17, 14-23.

Maltby, L., Jackson, M., Whale, G., Brown, A.R., Hamer, M., Solga, A. et al. (2017) Is an ecosystem services-based approach developed for setting specific protection goals for plant protection products applicable to other chemicals? Science of the Total Environment, 580, 1222-1236. 
Mann, C.C. (2011) 1493: How Europe's Discovery of the Americas Revolutionized Trade, Ecology and Life on Earth. Granta, London, UK.

Mansion-Vaquié, A., Ferrante, M., Cook, S.M., Pell, J.K. and Lövei, G.L. (2017) Manipulating field margins to increase predation intensity in fields of winter wheat (Triticum aestivum). Journal of Applied Entomology, DOI: 10.1111/jen.12385

Mészáros, Z., Ádám, L., Balázs, K., Benedek, I.M., Draskovits, Á.D., Kozár, F. et al. (1984) Results of faunistic studies in Hungarian maize stands. Acta Phytopathologica Academiae Scientiarum Hungaricae, 19, 65-90.

Meyer, S.T., Koch, C. and Weisser, W.W. (2015) Towards a standardized Rapid Ecosystem Function Assessment (REFA). Trends in Ecology \& Evolution, 30, 390-397.

Millennium Ecosystem Assessment (2005) Ecosystems and Human Well-being: Synthesis. Island Press, Washington, DC, USA.

Obonyo, D., Songa, J., Oyieke, F., Nyamasyo, G. and Mugo, S. (2008) Bt-transgenic maize does not deter oviposition by two important African cereal stem borers, Chilo partellus Swinhoe (Lepidoptera: Crambidae) and Sesamia calamistis Hampson (Lepidoptera: Noctuidae). Journal of Applied Biosciences, 10, 424-433.

Oksanen, J., Blanchet, F.G., Kindt, R., Legendre, P., Minchin, P.R., O’Hara, R.B. et al. (2015) Vegan: Community Ecology Package. Version 2.3-0. http://CRAN.Rproject.org/package= $=$ vegan

Peterson, G., Allen, C.R. and Holling, C.S. (1998) Ecological resilience, biodiversity, and scale. Ecosystems, 1, 6-18.

R Core Team (2015) R: A language and environment for statistical computing. R Foundation for Statistical Computing, Vienna, Austria. URL https://www.R-project.org/. 
Ranum, P., Peña-Rosas, J.P. and Garcia-Casal, M.N. (2014) Global maize production, utilization, and consumption. Annals of the New York Academy of Sciences, 1312, $105-112$.

Riechert, S.E. and Lockley, T. (1984) Spiders as biological control agents. Annual Review of Entomology, 29, 299-320.

Rosenheim, J.A., Kaya, H., Ehler, L., Marois, J.J. and Jaffee, B. (1995) Intraguild predation among biological-control agents: theory and evidence. Biological Control, 5, 303335.

Sommaggio, D. (1999) Syrphidae: can they be used as environmental bioindicators? Agriculture, Ecosystems \& Environment, 74, 343-356.

Stenoien, C., Nail, K.R., Zalucki J.M., Parry, H., Oberhauser, K.S., Zalucki, M.P. (2016). Monarchs in decline: a collateral landscape level effect of modern agriculture. Insect Science, DOI 10.1111/1744-7917.12404

Sunderland, K. and Samu, F. (2000) Effects of agricultural diversification on the abundance, distribution, and pest control potential of spiders: a review. Entomologia Experimentalis et Applicata, 95, 1-13.

Tscharntke, T., Klein, A.M., Kruess, A., Steffan-Dewenter, I. and Thies, C. (2005) Landscape perspectives on agricultural intensification and biodiversity-ecosystem service management. Ecology Letters, 8, 857-874.

Wu, K.M., Lu, Y.H., Feng, H.Q., Jiang, Y.Y. and Zhao, J.Z. (2008) Suppression of cotton bollworm in multiple crops in China in areas with Bt toxin-containing cotton. Science, 321, 1676-1678.

Zeilinger, A.R., Andow, D.A., Zwahlen, C. and Stotzky, G. (2010) Earthworm populations in a northern US Cornbelt soil are not affected by long-term cultivation of Bt maize 
expressing Cry1 Ab and Cry3Bb1 proteins. Soil Biology and Biochemistry, 42, 12841292.

Manuscript received April 24, 2017

Final version received July 27, 2017

Acceptd August 03, 2017 


\section{Text of the figures}

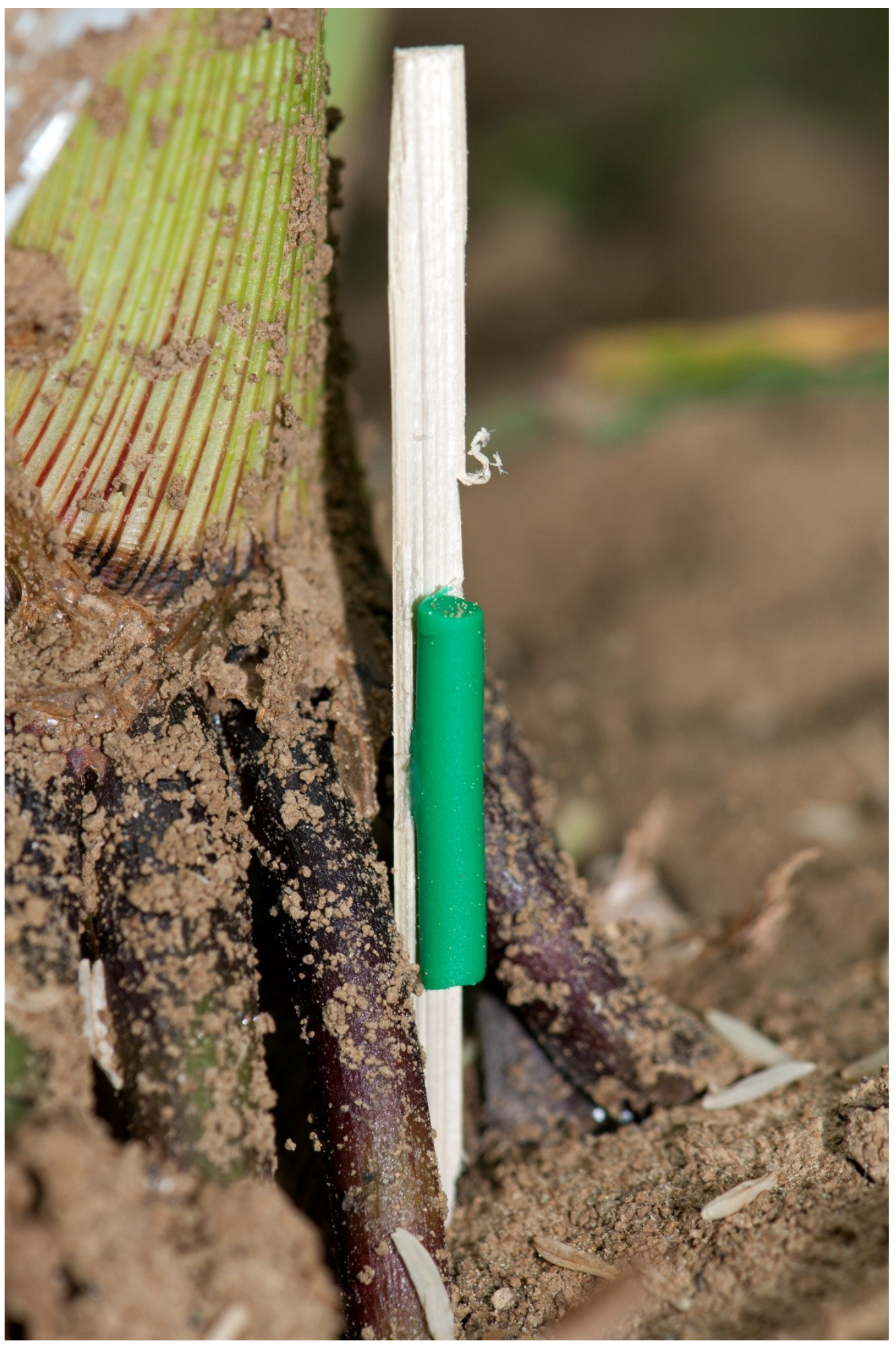

Fig.1 An artificial caterpillar exposed at the base of a maize plant, as if it were about to climb the maize stem. Photo: S. Magnanoli. 


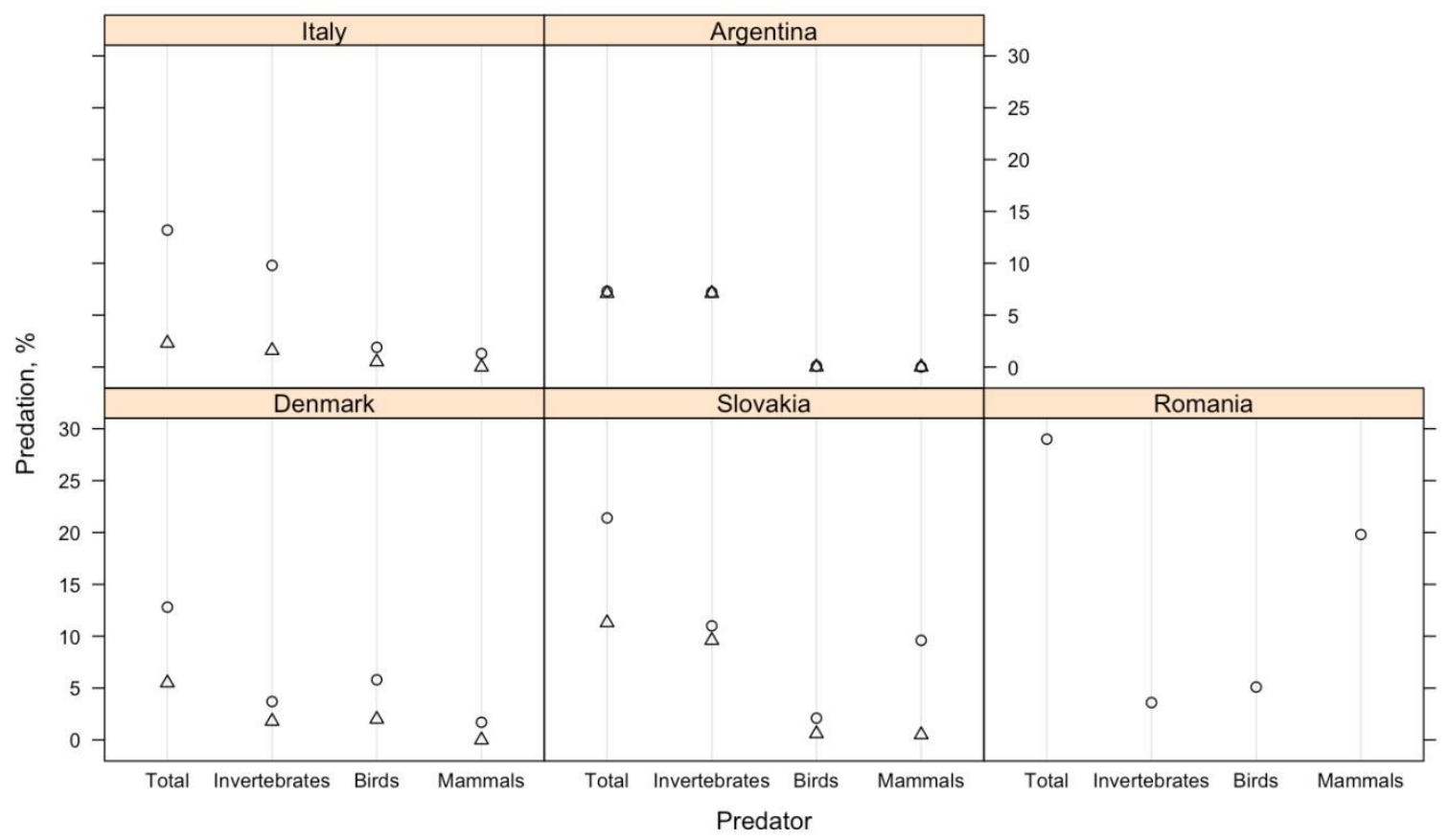

Fig.2 Predation intensity by country and predator group, at ground level (circles) and on canopy-placed (triangles) artificial caterpillars in maize fields in four European countries and Argentina.

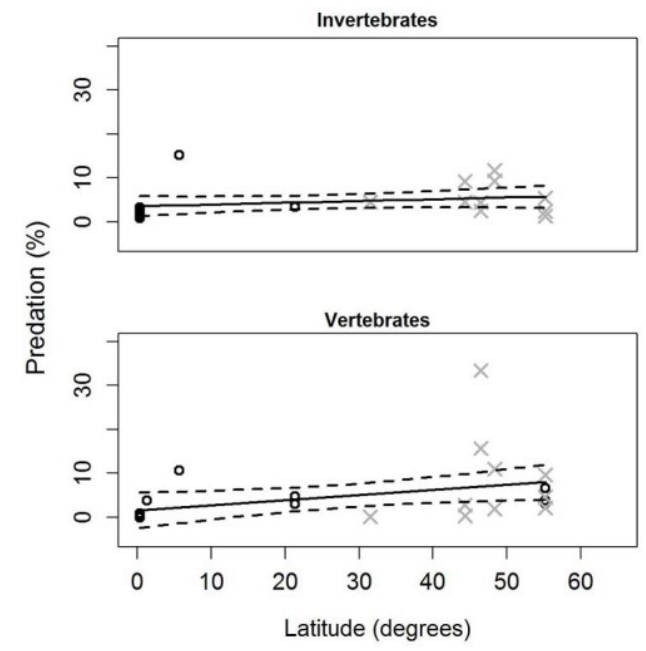

Fig 3 The relationship between geographical latitude (expressed in degrees) and predation rates measured using artificial caterpillars by invertebrate and vertebrate predators in cultivated areas. The solid lines represent the fit of a linear regression, dashed lines indicate \pm 
95\% CI. Regression equations: (invertebrates) $y=3.55702+0.03987 x, P=0.278$, adj. $R^{2}=$ 0.01229; (vertebrates) $y=1.56712+0.11638 x, P=0.057$, adj. $R^{2}=0.01113$. Circles indicate published data (modified from Lövei \& Ferrante [2017]), while crosses mark new data from this article. 
Table 1. Predation on artificial caterpillars in maize fields at ground and canopy levels for each country partner in the AMIGA project. Data are means \pm SD. Sample sizes are in parentheses.

\begin{tabular}{lll}
\hline Country & \multicolumn{2}{l}{ Predation rate (\%) on caterpillars placed on } \\
\cline { 2 - 3 } & Ground & Canopy \\
\hline Denmark & $12.8 \pm 33.4(2061) \mathrm{c}$ & $5.5 \pm 22.9(1249) \mathrm{b}$ \\
Slovakia & $21.4 \pm 41.0(957) \mathrm{b}$ & $11.3 \pm 31.6(959) \mathrm{a}$ \\
Romania & $29.0 \pm 45.4(845) \mathrm{a}$ & na \\
Italy & $13.2 \pm 33.8(1722) \mathrm{c}$ & $2.3 \pm 14.9(1462) \mathrm{c}$ \\
Argentina & $7.3 \pm 26.0(794) \mathrm{d}$ & $7.1 \pm 25.6(794) \mathrm{b}$ \\
& \\
\hline
\end{tabular}


Table 2. Relative predation rats ( $\%$ of all predation events) by different predatory groups in maize fields at ground and canopy levels in each country partner in the AMIGA project, organised by geographical latitude.

\section{Relative predation rate* by}

Prey position, Insects

country (except ants) Ants Birds Mammals Unknown

Ground level

Denmark

29.2

0

45.5

14

12.1

Slovakia

37.1

15.19 .8

44.9

1.0

Romania

11.4

0.8

17.6

68.2

3.7

Italy

72.3

3.1

14.1

10.1

1.8

Argentina

87.9

10.3

1.7

0

0

Maize canopy

$\begin{array}{lccccc}\text { Denmark } & 33.3 & 0 & 36.2 & 0 & 30.4 \\ \text { Slovakia } & 44.4 & 40.7 & 5.6 & 4.6 & 4.7 \\ \text { Romania } & \text { na } & \text { na } & \text { na } & \text { na } & \text { na } \\ \text { Italy } & 72.7 & 0 & 24.2 & 0 & 6.1 \\ \text { Argentina } & 100 & 0 & 0 & 0 & 0\end{array}$

\footnotetext{
* Note that multiple attacks by different predators on the same caterpillar may result in values $>100 \%$.
} 